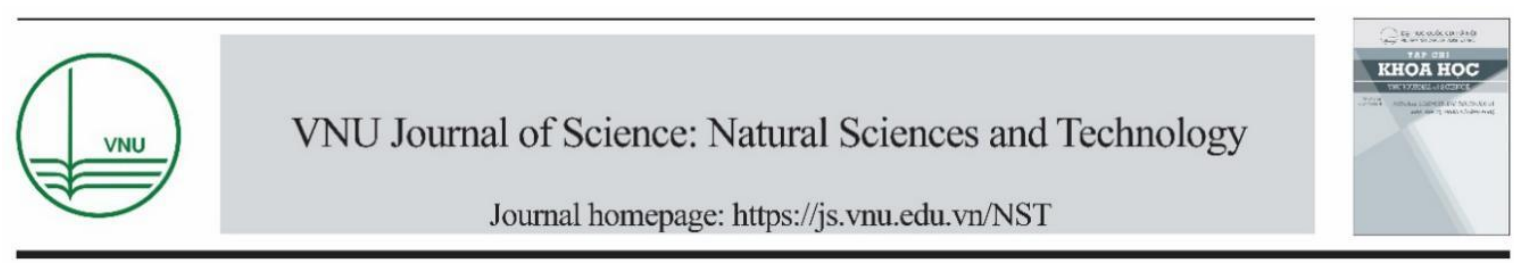

Original Article

\title{
Assessing Changes in Ecological Quality Status of Sediment in Tri An Reservoir (Southeast Vietnam) by using Indicator of Nematode Communities
}

\author{
Tran Thanh Thai ${ }^{1}$, Pham Thanh Luu ${ }^{1,2}$, Tran Thi Hoang Yen ${ }^{1}$, \\ Nguyen Thi My Yen ${ }^{1}$, Ngo Xuan Quang ${ }^{1,2, *}$ \\ ${ }^{1}$ Institute of Tropical Biology, Vietnam Academy of Science and Technology, \\ 85 Tran Quoc Toan Street, District 3, Ho Chi Minh City, Vietnam \\ ${ }^{2}$ Graduate University of Science and Technology, Vietnam Academy of Science and Technology, \\ 18 Hoang Quoc Viet, Hanoi, Vietnam
}

Received 12 November 2019

Revised 12 December 2019; Accepted 06 February 2020

\begin{abstract}
Nematode communities in Tri An Reservoir (Dong Nai Province, Southeast Vietnam) were explored in the dry season (March) and pre-rainy season (July) of 2019 and analyzed to evaluate their usage as bioindicators for ecological quality status of sediment. Nematode communities consisted of 23 genera belonging to 19 families, 8 orders for the dry and 24 genera, 17 families, 8 orders for the pre-rainy season. Several genera dominated in Tri An Reservoir such as Daptonema, Rhabdolaimus, Udonchus, and Neotobrilus indicated for organic enrichment conditions. The percentage of cp3\&4 and MI (Maturity Index) value in the dry season was higher than that in the pre-rainy season expressed the ecological quality status of sediment in the dry season were better than those in the pre-rainy season. Furthermore, the result revealed that MI and c-p\% composition can be used to evaluate the ecological quality status of sediment efficiently.

Keywords: Bioindicator, ecological quality status of sediment, freshwater habitats, maturity index, nematodes, reservoir.
\end{abstract}

\section{Introduction}

Contrasting to natural processes of lake formation, reservoirs are artificial or man-made lakes formed by building a dam across flowing rivers [1]. Artificial freshwater reservoirs are important water sources in many countries around the world [2]. Water in the reservoir has made a substantial contribution to human socioeconomic development in many ways, such

\footnotetext{
* Corresponding author.

Email address: ngoxuanq@gmail.com

https://doi.org/10.25073/2588-1140/vnunst.4973
} 
as hydroelectricity generation, irrigation, fisheries, and recreation or as water sources for domestic or industrial use [3,4]. Nowadays, new reservoirs are being built mainly for the purpose of power generation [5]. Thus, there have been more than 96,000 of dams and their reservoirs constructed since the 1950s [6]. As a result, ecological impacts of reservoir dams have been reported from diverse aspects such as i) barrier for seasonal migration paths of migratory fishes like anadromous fish [7], ii) eutrophication of reservoirs by plankton blooming [8], iii) causing negative impacts on biodiversity by losses of forests and changes in the river environment [9], iv) decreasing flow volumes in downstream and increase in substrate grain size by sediment trapping, etc. [10].

Vietnam is a Southeast Asian country, which is directly influenced by the subtropical humid monsoon climate with its annual rainfall is high [11]. Most of the territory is mountainous or hilly; therefore, it has good potential for water reserves and hydropower generation. Furthermore, rainfall, almost the only source of surface flow, concentrates in a few months in a year during the rainy season. Thus, there is an urgent need to be regulated by reservoirs. Vietnam has 800 medium and large dams and reservoirs, and 1,967 reservoirs with a storage capacity of at least $0.2 \mathrm{~km}^{3}$. Seven reservoirs have a capacity of at least $1 \mathrm{~km}^{3}$ such as Hoa Binh $\left(9.5 \mathrm{~km}^{3}\right)$, Thac Ba $\left(2.9 \mathrm{~km}^{3}\right)$, Tri An $\left(2.7 \mathrm{~km}^{3}\right)$, Tuyen Quang $\left(2.2 \mathrm{~km}^{3}\right)$, Dau Tieng $\left(1.6 \mathrm{~km}^{3}\right)$, Thac Mo $\left(1.4 \mathrm{~km}^{3}\right)$, and Yaly $\left(1.0 \mathrm{~km}^{3}\right)$ [12].

Tri An Reservoir (TAR) was built in 1986, which is a multi-purpose reservoir for hydropower generation (mainly), flood-control, domestic and industrial water use, irrigation, and fisheries [13]. Water from the reservoir directly and indirectly supplies domestic activities for millions of people in Southeast Vietnam mainly in Dong Nai, Binh Duong Provinces, and Ho Chi Minh City [14]. While studies and reviews on Tri An reservoir's geography are increasingly common $[15,16]$, to date, few studies have assessed the presence, fate, and biodiversities of aquatic fauna communities, especially for benthic fauna. Even fewer studies have been completed in ichthyology and phytoplankton communities. The fish fauna of Tri An reservoir reflects the fauna of the impounded Dong Nai and La Nga rivers, which is consisted of 109 species, belonging to 28 families and 9 orders [17]. Moreover, the phytoplankton community in TAR is known to constitute 197 species belonging to seven classes, Cyanophyceae (cyanobacteria), Chlorophyceae (green algae), Bacillariophyceae (diatoms), Chrysophyceae (golden algae), Xanthophyceae (yellow algae), Euglenophyceae (euglenoids) and Dinophyceae (dinoflagellates). Among them, cyanobacteria were abundant and dominant in the reservoir [18].

Inflowing rivers bring organic matter (especially for nitrogen and phosphorus compounds) and anthropogenic pollutants from upstream, loading them into reservoirs [3]. This leads to increased eutrophication, which often causes a mass proliferation of cyanobacteria [8]. In TAR, toxic cyanobacteria, cyanobacterial blooms and their toxins have been observed and reported in previous studies [14,18]. As cyanobacteria in a bloom die, its toxins were deposited in sediment; thus, sediment in reservoirs is also known as a sink or source of nutrients and toxins [3]. Because TAR is a domestic water supply for millions of people in Southern Vietnam, the ecological quality status of surface water, as well as sediment, should be given more concern.

The nematode communities (NC) or roundworms constitute the phylum Nematoda. They are small sediment-dwelling organisms and are among the most diverse phyla on earth [19]. They play a crucial role in component processes of most ecosystem services, such as nutrients, materials cycling, and energy flow in aquatic ecosystems [20,21]. In benthic food webs, nematodes are also known as trophic link between the microfauna and larger fauna [22]. On the other hand, because nematodes are i) the most abundant, and diversified in ecosystems, further are ii) sensitive and able to respond rapidly to natural and anthropogenic disturbance, they serve as elegant indicators of 
environmental disturbance $[21,23,24]$. Therefore, nematodes have pivotal roles in benthic ecosystems, as well as they are a meaningful tool for bioindicators in their environment.

Given the above-identified knowledge gaps and challenges, the current study aimed to i) describes the composition of NC in TAR, ii) to evaluate the ecological quality status of sediment (EcoQ) in TAR based on Maturity Index (MI) of NC. These findings can provide useful information to water resource management and monitoring as well.

\section{Materials and methods}

\subsection{Study area and sample collection}

Tri An Reservoir situated in Dinh Quan District, Dong Nai Province, Southeast Vietnam, about $70 \mathrm{~km}$ Northeast from Ho Chi Minh City (lies between latitudes $10^{\circ} 00^{\prime}$ to $12^{\circ} 20^{\prime}$ North and longitudes $107^{\circ} 00^{\prime}$ to $108^{\circ} 30^{\prime}$ East). The reservoir is mainly used for hydroelectricity generation [25]. TAR is the biggest reservoir of Vietnam, with a catchment area of approximately $14,800 \mathrm{~km}^{2}$, an average annual outflow of 15,100 million $\mathrm{m}^{3}$ and a total volume of $2,765 \mathrm{~km}^{3}$. The reservoir has a water surface area of around $324 \mathrm{~km}^{2}$, with an average depth of $8.5 \mathrm{~m}$, about $44 \mathrm{~km}$ in length and has a maximum width of $10 \mathrm{~km}$ [26]. The reservoir belongs to a tropical climate region, with annual rainfall and average temperature are $2,400 \mathrm{~mm}$ and $25.4^{\circ} \mathrm{C}$, respectively (Vietnam Ministry of Science Technology \& Environment, 2001). Furthermore, TAR contains about 50 coves of various sizes and connects to many tributaries of the Dong Nai and La Nga rivers [27].

Sampling was carried out in dry season (D, March) and pre-rainy season (PR, July) in 2019. A total of eight stations was sampled: DQ and LN (situated in upstream), TA1-5 (inside the reservoir), DN (downstream) (Fig. 1). Three sample replicates per station were taken by using a plastic core of $3.5 \mathrm{~cm}$ diameter and $30 \mathrm{~cm}$ high. The cores were pushed down into the sediment up to $10 \mathrm{~cm}$ depth and collected $10 \mathrm{~cm}^{2}$ surface area. The samples were all fixed in a 7\% formaldehyde solution (heated to $60^{\circ} \mathrm{C}$ ) and gently stirred before transportation to the laboratory of the Department of Environmental Management and Technology, Institute of Tropical Biology.

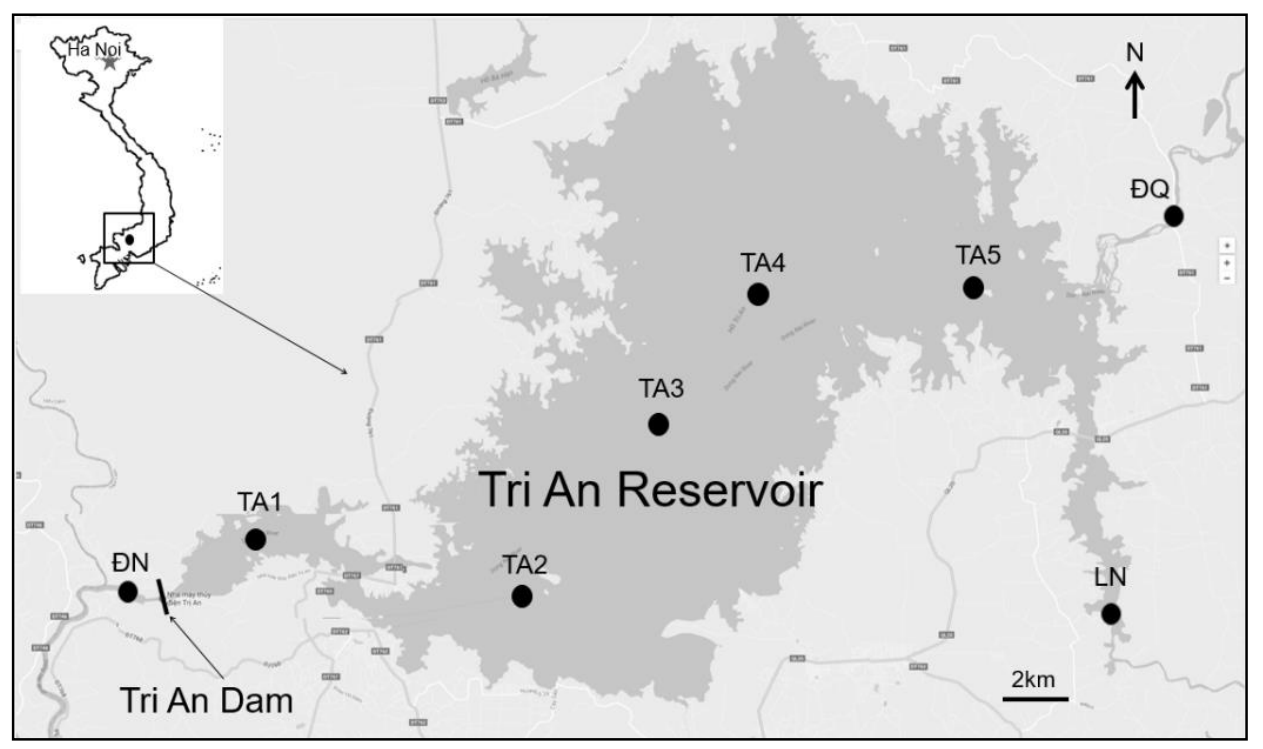

Fig. 1. Map of sampling stations in Tri An Reservoir, Dong Nai Province. 


\subsection{Sample handling and analyzing procedure}

In the laboratory, nematode samples were sieved through a $38 \mu \mathrm{m}$ mesh and extracted by a flotation technique with Ludox-TM50 solution (specific gravity of 1.18) [28]. Samples were stained with 3-5 mL Rose Bengal solution (1\%). All individual numbers were counted under a stereomicroscope, two hundred nematodes were used for making slides according to the guide of De Grisse (1969) for identification [29]. Nematodes were identified to genus level by using taxonomy literature, such as Abebe et al. (2006) [30] and Zullini (2010) [31].

\subsection{Data process and analysis}

2.3.1. Assessing the ecological quality status of sediment in Tri An Reservoir based on Maturity index of nematode communities

The maturity index (MI, [23,32]) was calculated as the weighted average of the individual colonisers persister (c-p) values:

$$
\mathrm{MI}=\sum_{i=0}^{n} v(i) * f(i)
$$

where $v$ is the cp value of genus $i$ and $f(i)$ is the frequency of that genus. This index has been proposed as a semiquantitative value giving an indication of ecosystem conditions according to the nematode assemblage composition.

The maturity index values are between 1 and 5 and can be converted in the EcoQ using the fixed scale provided by Moreno et al. (2011): High EcoQ, MI $>2.8$; Good EcoQ, 2.6<MI $\leq 2.8$; Moderate EcoQ, 2.4<MI $\leq 2.6$; Poor EcoQ, $2.2<\mathrm{MI} \leq 2.4$, and $\mathrm{Bad} \mathrm{EcoQ}, \mathrm{MI} \leq 2.2$ [33].

\subsubsection{Multivariate analyses}

Multivariate techniques like the Bray-Curtis multidimensional scaling ordination (MDS) were performed to present several dominant nematode genera from the different stations. Those analyses were carried out by the software PRIMER v.6.

\section{Results and Discussion}

\subsection{Describing nematode compositions and its changed throughout seasons}

In the dry season, NC in TAR, Dong Nai Province consisted of 23 genera belonging to 19 families, 8 orders (Chromadorida, Dorylaimida, Enoplida, Monhysterida, Mononchida, Plectida, Rhabditida, and Triplonchida), and 2 class (Enoplia-62.02\%, Chromadorea-37.98\%). In the dry season, most individuals belong to three dominant families: Xyalidae $(31.57 \%$ of total abundance), Rhabdolaimidae (25.07\%), and Mononchidae (14.61\%). The percentage of the remaining families ranged from $0.09 \%$ to $9.52 \%$. The dominant genera were Daptonema (30.63\%), Rhabdolaimus (24.22\%), and Mononchus (14.33\%) (Fig. 2). In total, 24 genera belonging to 17 families, 8 orders (Chromadorida, Dorylaimida, Enoplida, Monhysterida, Mononchida, Plectida, Rhabditida, and Triplonchida), and 2 class (Enoplia-48.70\%, Chromadorea-51.30\%) were found in the pre-rainy season in which Xyalidae had the highest abundance $41.45 \%$. The subdominant families were Rhabdolaimidae (19.52\%), Tobrilidae (16.23\%). The percentage of the remaining families ranged from $0.17 \%$ to $4.84 \%$. Furthermore, the dominant genera were Daptonema, Udonchus, and Neotobrilus with $40.76 \%, 17.79 \%$, and $16.23 \%$ of total abundance, respectively (Fig. 2, Appendix 1).

From dry to the pre-rainy season, genus Daptonema still dominated which was lead to the family Xyalidae further dominated in both seasons; however, in pre-rainy season, genus Daptonema dominated with a higher percentage rather than its in the dry season. The subdominant genera in dry season were Rhabdolaimus and Mononchus, whereas, Udonchus and Neotobrilus were the subdominant ones in the pre-rainy season; nevertheless, genera Rhabdolaimus and Udonchus belonged to the same family (Rhabdolaimidae). In the dry season, genus Daptonema was found more abundant in the upstream station (DN), while genera Rhabdolaimus and Mononchus were mostly occurred in the downstream station (DN). Regarding the pre-rainy season, genera Daptonema, Udonchus, and Neotobrilus were also found mainly inside the reservoir (TA1-5) (Fig. 3). 


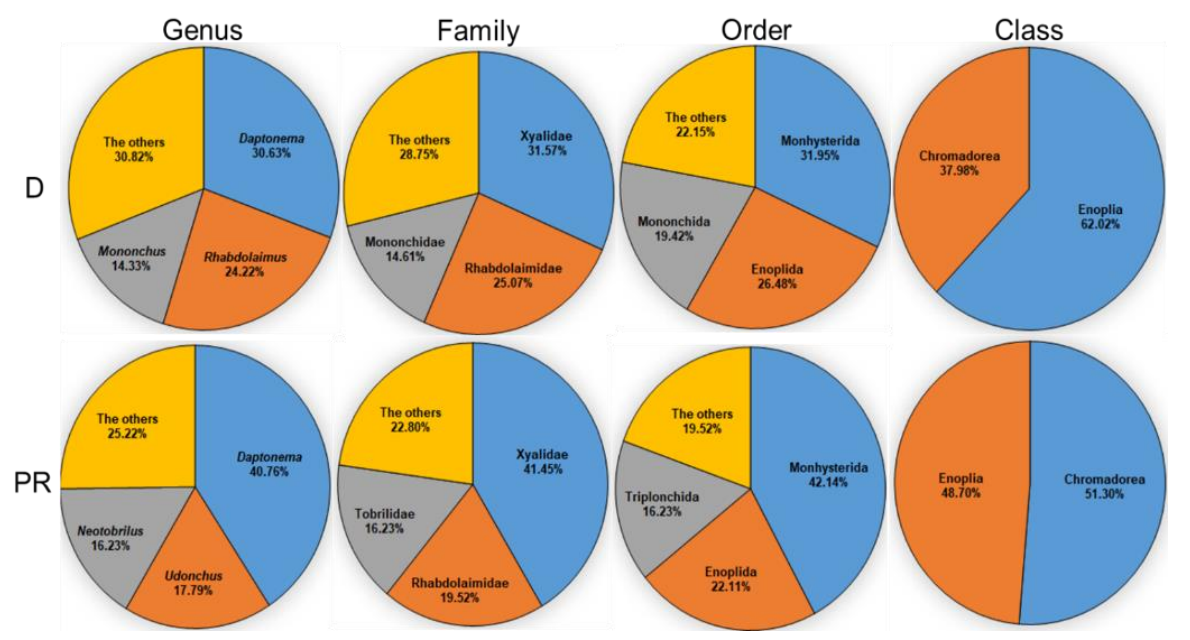

Fig. 2. Structure of nematode communities in TAR. (D) Dry season, (PR) Pre-rainy season.

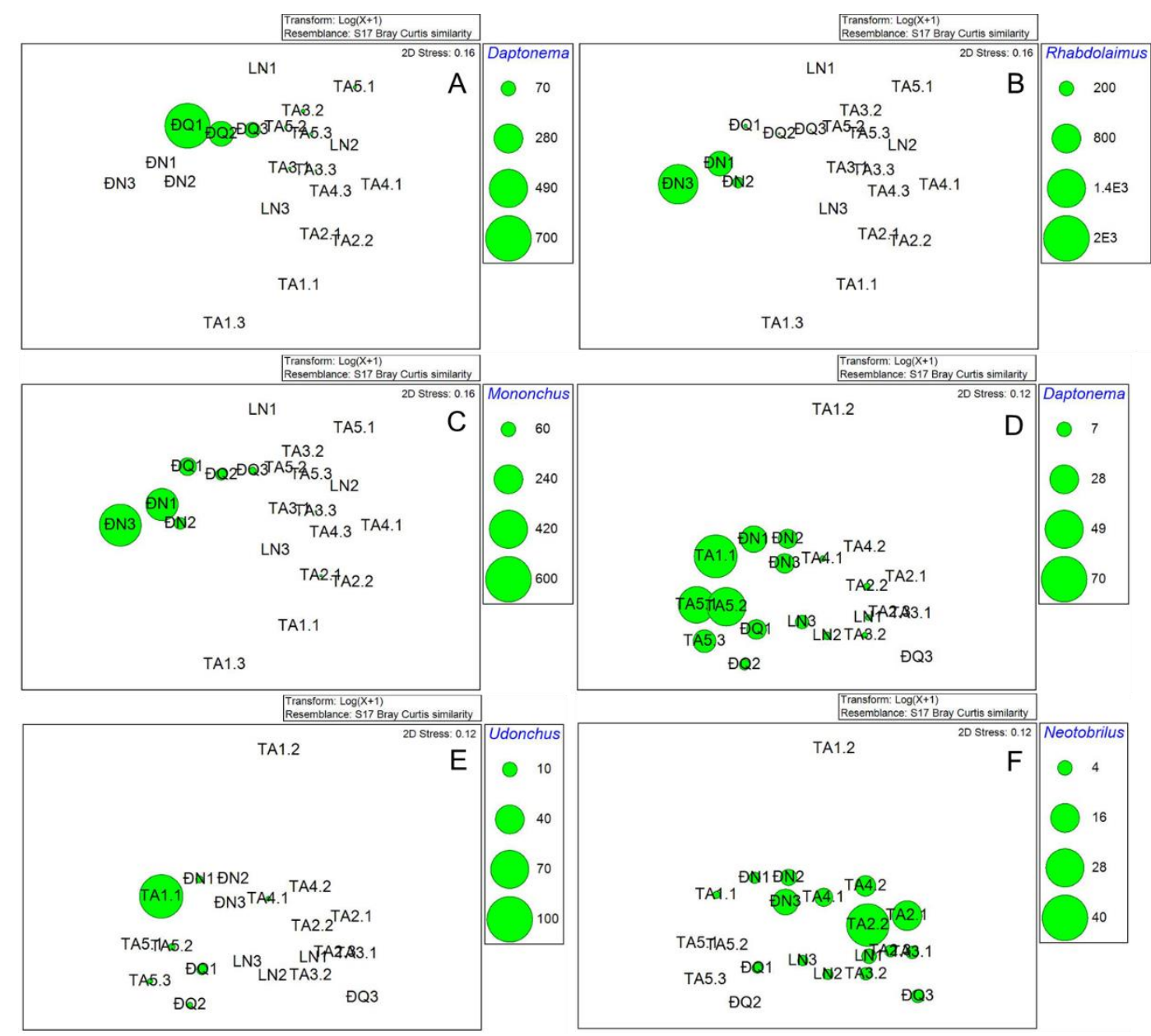

Fig. 3. MDS bubble plots for several dominant genera. In the dry season: (A) Daptonema, (B) Rhabolaimus, (C) Mononchus; In the pre-rainy season: (D) Daptonema, (E) Udonchus, (F) Neotobrilus. 
In general, these dominated genera in TAR might tolerate a wide range of environmental conditions. Nevertheless, several studies reported that they indicated for organic enrichment conditions such as genus Daptonema,
Rhabdolaimus, Udonchus, especially for genus Neotobrilus (be found in seriously polluted habitats). By contrast, genus Mononchus appeared to be an indicator of un- and sightly polluted conditions (Table 1).

Table 1. Several dominant genera in Tri An reservoir and their indicated characteristics. FT (Feeding type): B: bacterial feeder, S: substrate feeder, O: omnivore

\begin{tabular}{lccl}
\hline Genus & c-p & FT & Characteristics \\
Daptonema & 2 & S & $\begin{array}{l}\text { Known as an opportunistic genus in relation to heavy metals [34-36] and } \\
\text { hydrocarbons [37]. Indicators of pollution and organic enrichment } \\
\text { conditions [38] }\end{array}$ \\
Rhabdolaimus & 3 & B & $\begin{array}{l}\text { It is occurred widely from slightly to seriously polluted habitats, } \\
\text { especially for heavily polluted conditions [39] }\end{array}$ \\
Mononchus & 4 & O & $\begin{array}{l}\text { Appearances on medium to high contaminated conditions [30]. Most } \\
\text { abundant in organically enriched sediments [40]. }\end{array}$ \\
Neotobrilus & 3 & B & $\begin{array}{l}\text { It is found in seriously polluted habitats [39] } \\
\text { Tolerating a wide range of environmental conditions but it is found more } \\
\text { abundant in sites with medium to high contamination [30]. Several } \\
\text { species also occurred in polluted waters [41] }\end{array}$ \\
\hline
\end{tabular}

3.2. The ecological quality status of sediment in Tri An reservoir indicated by nematode communities

The MI based on a priori classification of nematode genera in one of five coloniserspersisters groups (c-p) ranging from extreme $r-$ strategists (colonisers) to extreme $\mathrm{k}$ - strategists (persisters). More specifically, five $\mathrm{cp}$ groups based upon different sensitivity levels (from very sensitive to opportunistic): cp5, 4, 3, 2, 1 which means decreasing levels of environmental disturbances $[23,32]$.

\subsubsection{Colonizers persister ( $c-p)$ index}

Most of the sampling stations in the dry season had a high percentage of cp4, except for station TA4 and DQ with a high percentage of cp1\&2. However, when compared to the dry season, the percentage of each cp group did vary so much in pre-rainy season where most of the stations had an extremely high percentage of cp1\&2, especially for station TA2, TA5, and LN. Contrastly, only station TA4 had a slight high percentage of cp4 (Table 2). This fluctuation might indicate that the EcoQ of TAR in the prerainy season more disturbing rather than its in the dry season.

Table 2. The percentage (\%) of each cp groups in nematode communities at the eight sampling station

\begin{tabular}{lllllllll}
\hline cp & \multicolumn{7}{c}{ Dry season } \\
\cline { 2 - 9 } groups & TA1 & TA2 & TA3 & TA4 & TA5 & LN & DQ & DN \\
\hline cp4 & 85.71 & 63.64 & 53.49 & 12.50 & 48.00 & 52.00 & 15.35 & 35.96 \\
cp3 & 0.00 & 0.00 & 0.00 & 4.17 & 0.00 & 20.00 & 2.63 & 61.70 \\
cp1\&2 & 14.29 & 36.36 & 46.51 & 83.33 & 52.00 & 28.00 & 82.02 & 2.34 \\
\cline { 2 - 9 } & Pre-rainy season & & & & & \\
\cline { 2 - 9 } cp4 & 8.84 & 2.13 & 0.00 & 53.85 & 4.39 & 22.73 & 30.61 & 33.33 \\
cp3 & 54.14 & 0.00 & 14.29 & 7.69 & 4.39 & 0.00 & 18.37 & 14.17 \\
cp1\&2 & 37.02 & 97.87 & 85.71 & 38.46 & 91.23 & 77.27 & 51.02 & 52.50 \\
\hline
\end{tabular}


The ecological triangle of NC was created based on the percentage of $\mathrm{cp}$ value in 3 groups such as cp4, cp3, and cp1\&2 (Table 2). In the dry season, because of the high percentage of cp1\&2 in station DQ and TA4 brought these stations to the right-bottom side of the triangle. This indicated that these stations migh be heavily impacted by environmental disturbances. In contrast, the station such as TA1, 2, 3, and LN had the high percentage of $\operatorname{cp} 3 \& 4$; thus, these stations located in the up-side of the triangle. This could also indicate that the EcoQ was fine or less impacted by disturbances. In the pre-rainy season, the number of stations with the high percentage of cp1\&2 increased when compared its in the dry season. Therefore, from dry to prerainy season, a tendency of these stations to move down the ecological triangle which was increasing levels of environmental disturbances (Fig. 4).
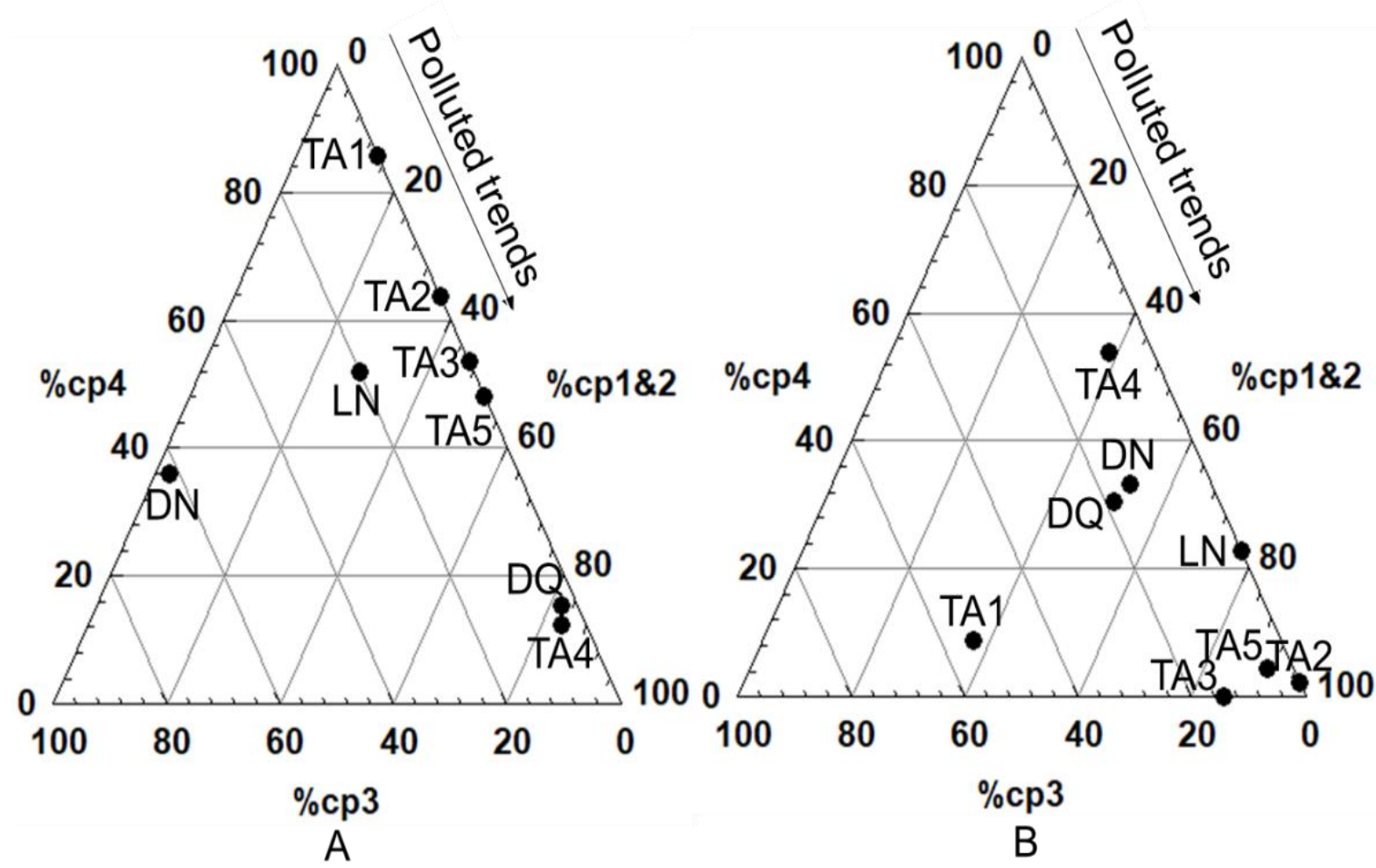

Fig. 4. The cp triangle with unweighted proportional representation of cp1, cp2, cp3, and cp4 group of the nematode communities. (A) Dry season, (B) Pre-Rainy season.

\subsubsection{Maturity index (MI)}

Overall, the MI ranged from $2.35 \pm 0.10$ to $3.50 \pm 0.70$ in dry and measured from $2.10 \pm 0.14$ to3.35 \pm 0.92 in pre-rainy season. The station TA1, 2, 3, 5, LN, and DN had the high MI value and could be classified as high EcoQ conditions. In turn, the station TA4 and DQ assigned to poor EcoQ status because of its low MI value. For the pre-rainy season, the high MI value observed in TA1, 4, DQ, and DN and its stations assigned to high, and good EcoQ status. Station TA2 and LN classified as poor EcoQ status whereas the bad EcoQ status observed in TA2, and TA5 because of its low MI value. Obviously, the EcoQ status in TAR in dry season expressed better conditions than its in the pre-rainy season (Fig 5). 


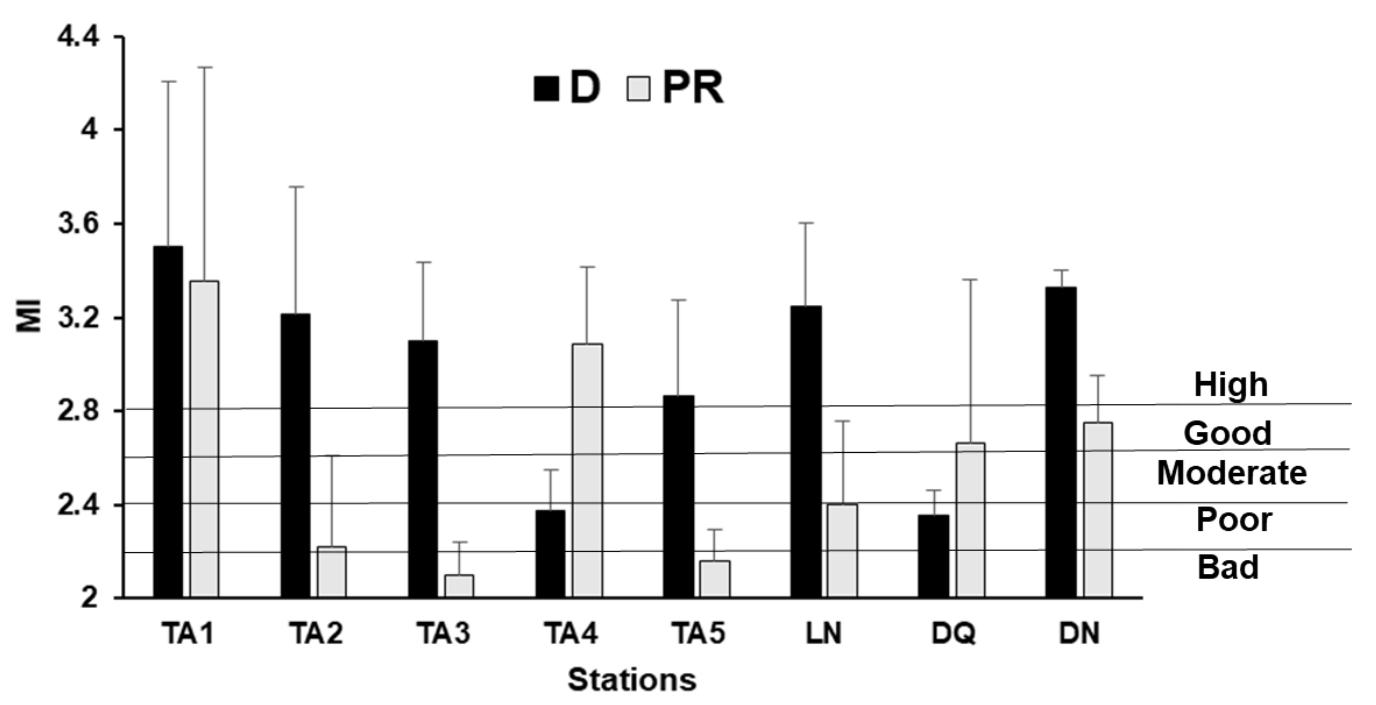

Fig. 5. MI value in each sampling station and changed in the ecological quality status of sediment throughout season.

There was increasing in the percentage of cp1\&2 group from dry to pre-rainy season. This indicated that the EcoQ in TAR was enriched by organic matter, particularly in the pre-rainy season. In fact, several nutrients (nitrite, ammonium, total nitrogen, and total phosphorus) and BOD5 parameter in surface water in TAR were analyzed, and their results showed that nutrient concentrations were the highest from June to August (pre-rainy season) and lowest in March (dry season). It demonstrated a richness of organic compounds for heterotrophic bacterial development [18]. This also explains why NC in TAR dominated by omnivore, bacterial, and substrate feeder nematodes, especially for the pre-rainy season. The main cause for this was during the rainy season in southern Vietnam (May-November), two rivers (La Nga and Dong Nai) have been bringing more organic and inorganic matter into the reservoir. In addition, fish caging activities and wastewater from a sugar factory located at the inflow of La Nga River have also been contributing to the nutrient enrichment [18].

The result of the present study was further supported by Ferris and Bongers (2006) [42], who reported that nematode assemblages had more responsive than others to resource enrichment. Nowadays, NC has been widely using in bioindicator studies [43]. The MI value has already been used for the assessment of the EcoQ in various environmental habitats such as Mediterranean coastal ecosystems [33], Black Sea [44], Beigang River Basin [39]. In Vietnam, using of the $\mathrm{MI}$ of $\mathrm{NC}$ for monitoring environmental qualities have emphasized in recent papers: Can Gio mangroves [45], Sai Gon River [46], Ba Lai River [47]. In this study, MI has been used for the first time in the assessment of EcoQ conditions in Tri An Reservoir, Dong Nai Province.

\section{Conclusion}

This is the first comprehensive study investigating $\mathrm{NC}$ and their ability to assess the EcoQ in TAR, Dong Nai Province. NC in TAR consisted of 24 genera belonging to 19 families, 8 orders in both sampling seasons. Several genera indicated for organic enrichment conditions such as genus Daptonema, Rhabdolaimus, Udonchus, Neotobrilus founded in TAR, especially for the pre-rainy season. The percentage of cp1\&2 increased from the dry to 
the pre-rainy season. Moreover, the MI value in the dry was higher rather than that in the prerainy season. This indicated that the EcoQ conditions in the dry were better than those in the pre-rainy season. Moreover, the EcoQ in TAR was enriched by organic matter, particularly in the pre-rainy season. The result also suggested that nematodes might be useful indicators for biomonitoring studies in freshwater habitats. However, the future study should pay more experience from field studies and laboratory experiments in order to better interpret changes in the composition of $\mathrm{NC}$, and thus to be able to use sophisticated indices, such as the MI, for ecological quality status assessment of sediment.

\section{Acknowledgment}

This research was funded by the Vietnam Academy of Science and Technology (VAST) under grant number KHCBSS.02/19-21. The author thanks the staff of the Department of Environmental Management and the Department of Biological Resources (ITB-VAST) for precious help with laboratory analyses.

\section{References}

[1] N.M. Hayes, B.R. Deemer, J.R. Corman, N.R. Razavi, K.E. Strock, Key differences between lakes and reservoirs modify climate signals: A case for a new conceptual model, Limnology and Oceanography Letters 2(2) (2017) 47-62. https:// doi.org/10.1002/lol2.10036.

[2] R.J. Hogeboom, L. Knook, A. Y. Hoekstra, The blue water footprint of the world's artificial reservoirs for hydroelectricity, irrigation, residential and industrial water supply, flood protection, fishing and recreation, Advances in water resources 113 (2018) 285-294. https://doi. org/10.1016/j.advwatres.2018.01.028.

[3] R.G. Wetzel, Limnology: Lake and river ecosystems (3rd edition), Elsevier Science, San Diego, 2001.

[4] D.E. Gernaat, P.W. Bogaart, D.P. van Vuuren, H. Biemans, R. Niessink, High-resolution assessment of global technical and economic hydropower potential, Nature Energy 2(10) (2017) 821. https:// doi.org/10.1038/s41560-017-0006-y.
[5] K. Timpe, D. Kaplan, The changing hydrology of a dammed Amazon, Science Advances 3(11) (2017) e1700611. https://doi.org/10.1126/sciadv. 1700611.

[6] L. Zeng, L. Zhou, D.L. Guo, D.H. Fu, P. Xu, S. Zeng, Q.D. Tang, A.L. Chen, F.Q. Chen, Y. Luo, G.F. Li, Ecological effects of dams, alien fish, and physiochemical environmental factors on homogeneity/heterogeneity of fish community in four tributaries of the Pearl River in China, Ecology and Evolution 7(11) (2017) 3904-3915. https:// doi.org/10.1002/ece3.2920.

[7] R. Freeman, W. Bowerman, T. Grubb, A. Bath, G. Dawson, K. Ennis, J. Giesy, Opening rivers to Trojan fish: The ecological dilemma of dam removal in the Great Lakes, Conservation in Practice 3 (2002) 35-40. https://doi.org/10.1111/j. 1526-4629.2002.tb00045.x.

[8] W.W. Carmichael, Cyanobacteria secondary metabolites-the cyanotoxins, Journal of Applied Bacteriology 72(6) (1992) 445-459. https://doi. org/10.1111/j.1365-2672.1992.tb01858.x.

[9] Carew-Reid, Jeremy, K. Josh, C. Alison, Biodiversity and Development of the Hydropower Sector: Lessons from the Vietnamese Experience -Volume I, in: Review of the Effects of Hydropower Development on Biodiversity in Viet Nam, ICEM-International Centre for Environmental Management, Prepared for the Critical Ecosystem Partnership Fund Hanoi Viet Nam (2010).

[10] G. Berkamp, M. McCartney, P. Dugan, J. McNeely, M. Acreman, Dams, Ecosystem Functions and Environmental Restoration Thematic Review II.1 prepared as an input to the World Commission on Dams, Cape Town, 2000.

[11] D.T. Ngo, C. Kieu, M. Thatcher, D. Nguyen-Le, T. Phan-Van, Climate projections for Vietnam based on regional climate models, Climate Research 60(3) (2014) 199-213. https://doi.org/ $10.3354 / \mathrm{cr} 01234$.

[12] J. Soussan, Strategic Environmental Assessment of Hydropower in the context of the Power Development Plan VI in Vietnam: Final report. SEI/ADB GMS Joint Publication, 2008.

[13] Vietnam Ministry Of Science, Technology and Environment, The valuable biodiversity and environment wetlands in Vietnam, Agricultural Publishing House Hanoi, 2001.

[14] T.S. Dao, G. Cronberg, J. Nimptsch, L.C. DoHong, C. Wiegand, Toxic cyanobacteria from Tri An Reservoir, Vietnam, Nova Hedwigia 90(3-4) (2010) 433-448. https://doi.org/10.1127/00295035/2010/0090-0433. 
[15] N.V. Hoang, D.V. Thuan, N.D. Roi, Study on the impact of the Tri An reservoir on its downstream groundwater level regime, Vietnam Journal of Earth Sciences 34(4) (2012) 465-476. https://doi. org/10.15625/0866-7187/34/4/2806 (in Vietnamese).

[16] M.T. Tan, D.V. Thuan, V.V. Ha, N.T. Tan, T.T.T. Ha, N.V. Tao, N.C. Quan, Assessment of sedimentation in Tri An reservoir by nuclear technique, geological analyses and GIS, Vietnam Journal of Earth Sciences 36(1) (2014) 51-60. https://doi.org/10.15625/0866-7187/36/1/4141.

[17] MoF, Fisheries resources of Vietnam Agricultural Publishing House Hanoi, 1996 (in Vietnamese),

[18] T.S. Dao, J. Nimptsch, C. Wiegand, Dynamics of cyanobacteria and cyanobacterial toxins and their correlation with environmental parameters in Tri An Reservoir, Vietnam, Journal of Water and Health 14(4) (2016) 699-712. https://doi.org/10. 2166/wh.2016.257.

[19] Z.Q. Zhang, Animal biodiversity: an update of classification and diversity in 2013, Zootaxa 3703(1) (2013) 5-11. https://doi.org/10.11646/zootaxa.37 03.1.3.

[20] P.A. Montagna, J.E. Bauer, D. Hardin, R.B. Spies, Meiofaunal and microbial trophic interactions in a natural submarine hydrocarbon seep, Oceanographic Literature Review 10(42) (1995) 882.

[21] F. Semprucci, M. Moreno, S. Sbrocca, M. Rocchi, G. Albertelli, M. Balsamo, The nematode assemblage as a tool for the assessment of marine ecological quality status: a case-study in the Central Adriatic Sea, Mediterranean Marine Science 14(1) (2013) 48-57. https://doi.org/10. $12681 / \mathrm{mms} .366$.

[22] M. Majdi, W. Traunspurger, Free-living nematodes in the freshwater food web: a review, Journal of Nematology 47(1) (2015) 28.

[23] T. Bongers, The maturity index: an ecological measure of environmental disturbance based on nematode species composition, Oecologia 83 (1990) 14-19.

[24] H. Ferris, T. Bongers, R.G.M. de Goede, A framework for soil food web diagnostics: extension of the nematode faunal analysis concept, Applied Soil Ecology 18 (2001) 13-29. https://doi. org/10.1016/S0929-1393(01)00152-4.

[25] DNFC, Assessment of potentials, current situation and planning for sustainable fisheries development in Tri An reservoir, Department of Agriculture and Rural Development Dong Nai, 1997 (in Vietnamese).

[26] DNFC, Annual technical reports on fisheries activities of Tri An reservoir from 1987-2005, Department of Agriculture and Rural Development, Dong Nai, 2005 (in Vietnamese).
[27] V.C. Luong, Y. Yi, C.K. Lin, Cove culture of marble goby (Oxyeleotris marmorata Bleeker) and carps in Tri An Reservoir of Vietnam, Aquaculture 244(1-4) (2005) 97-107. https://doi.org/10.1016/j.aquaculture.2004.10.027.

[28] M. Vincx, Meiofauna in marine and freshwater sediments, in: G. S. Hall (Eds.), Methods for the examination of organismal diversity in soils and sediments, Wallinfort UK, 1996.

[29] A.T. De Grisse, Redescription ou modifications de quelques technique utilis [a] es dan l'etude des $n$ [a] ematodes phytoparasitaires, 1969.

[30] E. Abebe, I. Andrássy, W. Traunspurger, Freshwater Nematodes: Ecology and Taxonomy, CABI, 2006.

[31] A. Zullini, The Identification manual for freshwater nematode genera, Lecture book, MSc Nematology Ghent University, 2005.

[32] T. Bongers, R. Alkemade, G.W. Yeates, Interpretation of disturbance induced maturity decrease in marine nematode assemblages by means of the Maturity Index, Marine Ecology Progress Series 76 (1991) 135-142.

[33] M. Moreno, F. Semprucci, L. Vezzulli, M. Balsamo, M. Fabiano, G. Albertelli, The use of nematodes in assessing ecological quality status in the Mediterranean coastal ecosystems, Ecological Indicators 11(2) (2011) 328-336. https://doi.org/ 10.1016/j.ecolind.2010.05.011.

[34] R.N. Millward, A. Grant, Assessing the impact of copper on nematode communities from a chronically metal metal-enriched estuary using pollutioninduced community tolerance, Marine Pollution Bulletin 30 (1995) 701-706. https://doi. org/10.1016/0025-326X(95)00053-P.

[35] A. Hedfi, E. Mahmoudi, F. Boufahja, H. Beyrem, P. Aïssa, Effects of increasing levels of nickel contamination on structure of offshore nematode communities in experimental microcosms, Bulletin of Environmental Contaminant and Toxicology 79 (2007) 345-349. https://doi.org/10. 1007/s00128-007-9261-0.

[36] F. Boufahja, A. Hedfi, J. Amorri, P. Aïssa, H. Beyrem, E. Mahmoudi, An assessment of the impact of chromium-amended sediment on a marine nematode assemblage using microcosm bioassays, Biological Trace Elements Research 142 (2011) 242-255. https://doi.org/10.1007/ s12011-010-8762-6.

[37] E. Mahmoudi, N. Essid, H. Beyrem, A. Hedfi, F. Boufahja, P. Vitiello, P. Aïssa, Effects of hydrocarbon contamination on a free living marine nematode community: results from microcosm experiments, Marine Pollution Bulletin 50 (2005) 1197-1204. . https://doi.org/10. 1016/j.marpolbul.2005.04.018. 
[38] A.S. Alves, H. Adão, T.J. Ferrero, J.C. Marques, M. J. Costa, J. Patrício, Benthic meiofauna as indicator of ecological changes in estuarine ecosystems: the use of nematodes in ecological quality assessment, Ecological Indicators 24 (2013) 462-475. https://doi.org/10.1016/j.ecolind. 2012.07.013.

[39] H.C. Wu, P.C. Chen, T.T. Tsay, Assessment of nematode community structure as a bioindicator in river monitoring, Environmental Pollution 158(5) (2010) 1741-1747. https://doi.org/10.1016/j.envpol. 2009.11.015.

[40] R. Niemann, M. Arens, K. Koczwara, D. Sturhan, Untersuchungen über die Eignung von Nematoden zur Gütebewertung von Fließgewässern, Mitteilungen der biologischen Bundesanstalt für Land-Forstwirtschaft, Berlin-Dahlem 317 (1996) 195-208.

[41] A.H. Arthington, G.W. Yeates, D.L. Conrick, Nematodes, including a new record of Tobrilus diversipapillatus in Australia, as potential indicators of sewage effluent pollution, Australian Journal of Marine and Freshwater Research 37 (1986) 159-166.https://doi.org/10.1071/MF9860159.

[42] H. Ferris, T. Bongers, Nematode indicators of organic enrichment, Journal of Nematology 38(1) (2006) 3-12.

[43] X.Q. Ngo, N.C. Nguyen, M. Nic, P. Larisa, V. Ann, Intertidal nematode communities in the
Mekong estuaries of Vietnam and their potential for biomonitoring, Environmental Monitoring and Assessment 188(2) (2016) 1-16. https://doi.org/ 10.1007/s10661-016-5091-z.

[44] D. Ürkmez, M. Sezgin, L. Bat, Use of nematode Maturity Index for the determination of ecological quality status: a case study from the Black Sea, Journal of Black Sea/Mediterranean Environment 20(2) (2016) 96-107.

[45] T.L. Ngo, X.Q. Ngo, Using the Maturity Index (MI) of nematode communities as bioindicator to assess water quality in Khe Đoi and Wastewater waterways in the Can Gio mangrove forest, Ho Chi Minh City, Journal Science 47(81) (2013) 132 - 141 (in Vietnamese).

[46] T.M.Y. Nguyen, X.Q. Ngo, Rapid assessment of sediment environmental quality in the Sai Gon River harbors by applying MI index and $\mathrm{cp}$ triangle of free living nematodes, the proceeding of International workshop on environment and climate change - challenge, response and lesson learnt (2015) 95-102.

[47] T.T. Tran, Q.L. Nguyen Le, T.M.Y. Nguyen, N.S. Hoang, N.X. Ngo, Nematode communities as a tool for the assessment of ecological quality status of sediment: the case of Ba Lai river, Ben Tre province, Journal of Biotechnology 15(3A) (2017) 295-302. 


\section{Appendix}

Appendix 1. Structure of nematode communities in Tri An Reservoir

\begin{tabular}{lllllc}
\hline \multicolumn{1}{c}{ Genus } & \multicolumn{1}{c}{ Family } & \multicolumn{1}{c}{ Order } & \multicolumn{1}{c}{ Class } & Dry & P-Rainy \\
\hline Achromadora & Achromadoridae & Chromadorida & Chromadorea & + & + \\
Aphanonchus & Aphanolaimidae & Plectida & Chromadorea & & + \\
Aphelenchoides & Aphelenchoididae & Rhabditida & Chromadorea & + & \\
Cephalobus & Cephalobidae & Rhabditida & Chromadorea & + & \\
Chromadorita & Chromadoridae & Chromadorida & Chromadorea & + & + \\
Cobbonchus & Mononchidae & Mononchida & Enoplia & + & + \\
Cryptonchus & Cryptonchidae & Mononchida & Enoplia & + & + \\
Daptonema & Xyalidae & Monhysterida & Chromadorea & + & + \\
Dichromadora & Chromadoridae & Chromadorida & Chromadorea & & + \\
Goffartia & Diplogastridae & Rhabditida & Chromadorea & & + \\
Ironus & Ironidae & Enoplida & Enoplia & + & + \\
Mesodorylaimus & Dorylaimidae & Dorylaimida & Enoplia & + & + \\
Mononchulus & Mononchulidae & Mononchida & Enoplia & + & + \\
Mononchus & Mononchidae & Mononchida & Enoplia & + & + \\
Monshystera & Monhysteridae & Monhysterida & Chromadorea & + & + \\
Monshystrella & Monhysteridae & Monhysterida & Chromadorea & + & + \\
Mylonchulus & Mylonchulidae & Mononchida & Enoplia & + & + \\
Neotobrilus & Tobrilidae & Triplonchida & Enoplia & + & + \\
Paractinolaimus & Actinolaimidae & Dorylaimida & Enoplia & + \\
Paracyatholaimus & Cyatholaimidae & Chromadorida & Chromadorea & & + \\
Paraplectonema & Leptolaimidae & Plectida & Chromadorea & + & + \\
Plectus & Plectidae & Plectida & Chromadorea & + & + \\
Ptycholaimelus & Chromadoridae & Chromadorida & Chromadorea & & + \\
Prismatolaimus & Prismatolaimidae & Triplonchida & Enoplia & + & + \\
Rhabditidoides & Diplogastridae & Rhabditida & Chromadorea & + & + \\
Rhabdolaimus & Rhabdolaimidae & Enoplida & Enoplia & + & + \\
Theristus & Xyalidae & Monhysterida & Chromadorea & + & + \\
\hline Tdonchus & Linhomoeidae & Monhysterida & Chromadorea & & + \\
\hline
\end{tabular}

